\title{
AUDIT REPORT DELAY AND AUDIT FIRM ROTATION IN TURKEY*
}

\author{
Koray TUAN ${ }^{1}$ \\ Mehmet Ünsal MEMİș \\ Faruk KAYGUSUZ ${ }^{3}$ \\ Zeinab CHEGINI ${ }^{4}$
}

\begin{abstract}
Lengthy delays in the publication of financial reports may adversely affect the efficiency of capital markets. The current study investigates the effect of auditing firm rotation on financial report disclosure dates. Accordingly, 1,200 company-year observations obtained from annual reports of non-financial institutions traded on the Borsa Istanbul for the years 2010-2017 are analyzed. The results of the current study indicate that there is a statistically significant positive relationship between financial report disclosure dates and audit firm rotation. In other words, financial report delay is longer following audit firm rotation. The results of the study are expected to provide benefits to regulatory authorities in the publication of timely financial reports necessary for the effective functioning of the capital market.
\end{abstract}

Keywords: Audit Firm Rotation, Financial Reporting, Audit Report Delay

\section{DENETIM RAPORU GECİKME SÜRESİ VE DENETIM FİRMASI ROTASYONU: TÜRKIYE ÖRNEĞI}

\section{ÖZ}

Bağımsız denetim sürecinden geçmiş finansal raporların yayımlanmasında yaşanan gecikmeler, sermaye piyasalarının etkin ișleyișini olumsuz yönde etkileyebilmektedir. Bu çalıșmada, bağımsız denetim firması değişikliğinin şirketin finansal raporlarını yayımlama süresi üzerindeki etkisi incelenmiştir. Bu doğrultuda, Borsa İstanbul'da işlem gören finansal olmayan kuruluşların 2010-2017 yıllarına ait yıllık faaliye raporlarından elde edilen 1.200 şirket-yıl verisi analiz edilmiştir. Çalışmanın sonuçları, şirketin finansal raporlarını yayımlama süreleri ile bağımsız denetim firması değişikliği arasında istatistiksel olarak anlamlı pozitif yönlü bir ilişki olduğuna işaret etmektedir. Diğer bir ifadeyle, bağımsız denetim firması değişikliği sonrasında şirketin finansal raporlarını açıklama tarihi uzamaktadır. Çalışma sonucunun, sermaye piyasasının etkin işleyişi için gerekli olan zamanlı finansal raporların yayımlanmasında düzenleyici kurum ve kuruluşlara fayda sağlaması beklenmektedir.

Anahtar Kelimeler: Denetim Firması Rotasyonu, Finansal Raporlama, Denetim Raporu Gecikmesi.

\footnotetext{
${ }^{1}$ Assoc. Prof., Cukurova University, Business Administration Department, ktuan@cu.edu.tr, ORCID:00000002-2168-6481.

2 Assoc. Prof., Cukurova University, Business Administration Department, mmemis@cu.edu.tr, ORCID: 0000-0003-1970-0480.

3 Ph.D. Candidate, Cukurova University, Business Administration Department, fkaygusuz@cu.edu.tr, ORCID: 0000-0001-6862-7238.

${ }^{4}$ Ph.D. Candidate, Cukurova University, Business Administration Department, zeynab.chegini@yahoo.com, ORCID: 0000-0002-5210-1861.

* Extended and Revised version of the paper presented at the 18th International Business Congress, Osmaniye, May 02-04 2019.

Received/Geliș: 23/01/2020 Accepted/Kabul: 06/02/2020, Research Article/Araștırma Makalesi

Cite as/Alıntı: Tuan, K., Memiş, M. Ü., Kaygusuz, F., Chegini, Z. (2020), “Audit Report Delay And Audit Firm Rotation In Turkey”, Çukurova Üniversitesi Sosyal Bilimler Enstitüsü Dergisi, cilt 29, sayı 1, s.29-41.
} 
Ç.Ü. Sosyal Bilimler Enstitüsü Dergisi, Cilt 29, Say1 1, 2020, Sayfa 29-41

\section{Introduction}

The financial statements are considered the outcome of the accounting process and they provide useful financial information to managers, inverstors and other users in the decision-making process. In order to make the right decisions, the information in the decision process would be valid, reliable and timely. (IASB, 2010). In addition, according to international accounting standards, financial information should have timely and reliable characteristics to ensure the efficiency of capital markets and quality financial reporting (Puasa et al., 2014: 162). Because lengthy delays in the disclosure of financial statements cause uncertainty in decisions taken through financial statements (Bamber et al., 1993) and at the same time lead to information asymmetry, thus reducing the quality of financial reports (Sultana et al., 2015: 72). This may undermine confidence in audited financial reports submitted to the capital markets in the long run. The most appropriate way to prevent this adverse situation is through reliable and timely financial reports obtained after the quality independent audit process. (Mohammadi et al., 2015: 2).

Following a series of accounting scandals caused by fraudulent financial reporting in the early 2000s, various regulations have been put into effect in order to regain trust in the audit profession, especially in the US and European Union countries. One of the noteworthy arrangements is the rotation practice of the audit partner or audit firm requested by policymakers, regulatory and supervisory authorities, practitioners and academics to reduce the intimacy of the auditor-customer management and strengthen the auditor's independence caused by the long-term relationship (Jackson et al., 2008; Firth et al., 2012). On the other hand, the major criticism of the audit firm rotation, mandatory or voluntary, is the loss of audit experience and detailed information gained by the auditor over the years after the change (Lee et al., 2009; Habib \& Bhuiyan, 2011). Therefore, this situation is likely to have a negative impact on the publication times of the financial reports issued at the end of the audit process. In this context, the objective of this study is to examine whether the date of publication of financial reports of non-financial companies listed on Borsa Istanbul (BIST) is affected by the audit firm rotation.

The timing of the release of an audit report in capital markets is a valuable input for those who make strategic investment decisions through the financial reports. Therefore, arrangements are made by the responsible institutions on Borsa Istanbul regarding this issue. Companies listed on a stock exchange, to prepare their financial statements on the basis of Turkish Accounting / Financial Reporting Standards (TAS / TFRS) and are obliged to disclose to the public. The principles, procedures and codes related to these obligations of the companies are regulated by the Communique on Principles of Financial Reporting in Capital Markets numbered II-14.1 published by the Capital Markets Board (CMB). This Communique has been promulgated in the Official Gazette edition 28676 on 13/6/2013 in order to comply with the Capital Market Law no. 6362 and the modernizations introduced by the Turkish Commercial Code no. 6102.

Firstly; in the Communique Serial: XI, No: 25 on Accounting Standards in Capital Markets prepared in 2003 on the basis of International Accounting / Financial Reporting Standards (IAS / IFRS) and later in the Communique on Principles Relating to Financial Reporting in Capital Markets, Serial: XI, No: 29, prepared taking into 
account the regulations of the European Union on financial reporting in 2008 and the provisions of the new Turkish Commercial Code, the legal periods for disclosure of financial reports should not exceed ten weeks after the end of the accounting period in absence of the obligation to prepare consolidated financial statements; under obligation to prepare consolidated financial statements, it was required to inform CMB and BIST within fourteen weeks following the end of the accounting period. Then, with another Communique (II-14.1 Communique on Financial Reporting in Capital Markets) published by $\mathrm{CMB}$, the basis for disclosure of financial reports to the public rather than to the board and stock exchange was adopted and the periods to be adhered to were also shortened. However, this Communique was regulated by a recent amendment in the Official Gazette edition 29968 in 2017 as follows:

Entities the securities of which are traded in an exchange and/or in other organized marketplaces are required to disclose to public their annual financial reports and their independent audit reports;

(a) Within 60 days and 70 days for unconsolidated and consolidated respectively, for the interim financial statements 30 days and 40 days unconsolidated and consolidated respectively. Where interim financial statements are subject to independent audit, the periods of time are increased by 10 days for entities the securities of which are traded in an exchange and/or in other organized marketplaces, and by 15 days for other entities.

(b) Entities other than those covered by the previous paragraph are required to disclose to public their annual financial reports and their independent audit reports, 3 weeks prior to the date of meeting of the general assembly of shareholders where the said financial reports will be discussed, and in any case, by the end of the 3rd month following the end of the relevant accounting period.

(c) If and when the last day of disclosure of financial reports coincides with an official holiday, then the first business day immediately after that official holiday will be applied as the last date of disclosure.

With this latest regulation, it is aimed to reduce the negativities that may arise from information asymmetry in the capital market and to protect the healthy development of financial markets.

The remainder of this paper is organized as follows. In the second section, both national and international literatures on the subject are summarized. The hypothesis of the study is developed in accordance with the previous studies and in line with the purpose of the study. In the third section, we introduce the study research method. In the fourth section, we provide the results of this study, and section five presents concluding remarks and recommendations.

\section{Literature Review and Hypothesis Development}

Accounting scandals caused by unethical behavior such as Enron, WorldCom and Parmalat in capital markets show the importance of timely and reliable disclosures of financial reports. Since inequality of access to information among users of financial statements leads to unfairness between the investors who are well informed in a timely manner and others, and this reduces the sense of trust in financial markets (Enofe et al., 2013:13). Moreover, investors perceive financial reports that cannot be published in 
time as a signal of bad news; and the delay of financial disclosure could lead to reducing of yield of the entities (Chambers \& Penman, 1984; Dao \& Pham, 2014: 491). Therefore, it is not surprising that both the regulatory authorities and users of the financial statements focus on timely and reliable financial reporting.

Timely audited financial reports are needed for optimal resource allocation in the capital markets, and it is possible to find many studies in the international literature to determine the factors that may affect the disclosure date of financial reports. In some studies, the association between the timeliness of financial statements and company characteristics such as firm size, sector type, leverage rate, profitability (Ashton \& Wright, 1989; Ettredge \& Sun, 2006; Munsif et al., 2012) or firm value (Givoly \& Palmon, 1982; Blankley et al., 2014) have been investigated. In another previous studies, it has been investigated whether corporate governance practices of companies (Bedard \& Gendron, 2010; Al-Ajmi, 2008; Afify, 2009; Abernathy et al., 2017), characteristics of audit firms and auditors such as size of the audit firm, tenure of audit service, auditor expertise (Lee et al., 2009; Knechel \& Sharma, 2012; Dao \& Pham, 2014) or audit rotation (Schwartz \& Soo, 1996; Tanyi et al., 2010; Enofe et al., 2013) have an effect on the date of publication of the audit report.

Referring to the studies in Turkey, although this issue is not as rich as the international literature, mostly the company's characteristics such as company size, type of sector, profit / loss announcements; audit firm and auditor characteristics such as the size, reputation, independent auditor opinion or characteristics of the audit committee of the company have been investigated in a limited manner (studies related to on the subject in Turkey and their results are fully presented in Table I). However, especially after the new regulations on audit rotation system in recent years, there is a research gap related to the effect of rotation application on the dates of disclosure of financial reports. As a result of the attempts to improve the transparency of financial reporting process and the quality of audit services in capital markets, public companies in Turkey are currently subject to mandatory auditor rotation. The opponents to audit rotation practice have two basic assumptions. The first assumption is that the audit fees at the first years of audit tenure will be increased by the additional audit procedure implementation and high start-up costs (Chen et al., 2008; Davis et al., 2009). Because, at the beginning of the audit agreement, auditors are obliged to bear additional costs in matters that are of great importance for the audit procedures, such as recognizing the accounting system of the client, achieving sufficient information about the operations and examining the internal control system. In addition, inefficient audit procedures raise costs due to the loss of specific knowledge about the client (Myers, et al., 2003). The second assumption is that the auditor needs time to access knowledge and experience of the client and industry that firm operates in (Arrunada \& Paz-Ares, 1997). Therefore, the audit rotation decreases the audit quality performed in the early years by causing lack of experience with the audited firm's practices has gained over the years (Geiger \& Raghunandan, 2002). We argue that the longer audit tenure is expected to produce timely financial reports as the auditor will be familiar with the weaknesses in the accounting system of the client, easily identifying risky transactions and less time for opening balances. In other words, the audit firm change will result in the auditor losing specific information about the client's operations and inefficient audit procedures, which may extend the period of publication of the audit report. 
Table 1. Audit Report Lag Literature in Turkey

\begin{tabular}{|c|c|c|c|}
\hline Reference & Variables & Sample-Period & Findings \\
\hline $\begin{array}{l}\text { Dogan, Coskun \& } \\
\text { Celik } \\
(2007)\end{array}$ & $\begin{array}{l}\text { Profitability, } \\
\text { company size, } \\
\text { financial risk, } \\
\text { industry. }\end{array}$ & $\begin{array}{l}\text { Corporate } \\
\text { Governance Index } \\
\text { of the Borsa } \\
\text { Istanbul for the } \\
\text { year } 2005 \text {. }\end{array}$ & $\begin{array}{l}\text { Timeliness of financial } \\
\text { statements is positively } \\
\text { affected by profitability. }\end{array}$ \\
\hline $\begin{array}{l}\text { Turel } \\
(2010)\end{array}$ & $\begin{array}{l}\text { Company size, } \\
\text { income, auditor } \\
\text { opinion, audit } \\
\text { firm and } \\
\text { industry. }\end{array}$ & $\begin{array}{l}211 \text { non-financial } \\
\text { companies from } \\
\text { Borsa Istanbul for } \\
\text { the year } 2007 .\end{array}$ & $\begin{array}{l}\text { Companies have net } \\
\text { income, standard audit } \\
\text { opinion, and operate in } \\
\text { manufacturing industry } \\
\text { release their financial } \\
\text { statements earlier while } \\
\text { companies are audited } \\
\text { by big four audit firms } \\
\text { report their financial } \\
\text { statements later. }\end{array}$ \\
\hline $\begin{array}{l}\text { Aktas \& Kargin } \\
(2011)\end{array}$ & $\begin{array}{l}\text { Financial } \\
\text { statement type, } \\
\text { profit or loss } \\
\text { announcement } \\
\text { and industry. }\end{array}$ & $\begin{array}{l}\text { Companies from } \\
\text { Borsa Istanbul. } \\
2005-2008 .\end{array}$ & $\begin{array}{l}\text { There is relationship } \\
\text { between financial } \\
\text { statement type, profit or } \\
\text { loss announcement, } \\
\text { industry and disclosure } \\
\text { dates of financial } \\
\text { reports. }\end{array}$ \\
\hline $\begin{array}{l}\text { Dumlu \& Saltoglu } \\
\text { (2011) }\end{array}$ & Sector type & $\begin{array}{l}78 \text { firms from } \\
\text { BIST-100 Index. } \\
2005-2009 .\end{array}$ & $\begin{array}{l}\text { The financial reporting } \\
\text { dates of firms operating } \\
\text { in finance and } \\
\text { manufacturing sectors } \\
\text { are not statistically } \\
\text { different from each } \\
\text { other. }\end{array}$ \\
\hline $\begin{array}{l}\text { Ozkan, } \\
\text { Karaibrahimoglu, } \\
\text { Acar \& Oz } \\
\text { (2013) }\end{array}$ & $\begin{array}{l}\text { Audit firm, } \\
\text { industry and } \\
\text { financial } \\
\text { performance. }\end{array}$ & $\begin{array}{l}\text { Companies from } \\
\text { Borsa Istanbul. } \\
2005-2010 .\end{array}$ & $\begin{array}{l}\text { Being audited by Big- } 4 \\
\text { firms shortens the } \\
\text { financial reporting date } \\
\text { of consolidated financial } \\
\text { statements. }\end{array}$ \\
\hline $\begin{array}{l}\text { Yucel, Ertan } \\
\text { \&Sarac } \\
(2013)\end{array}$ & $\begin{array}{l}\text { Corporate } \\
\text { governance level } \\
\text { of companies. }\end{array}$ & $\begin{array}{l}\text { Companies that } \\
\text { publish } \\
\text { unconsolidated } \\
\text { financial } \\
\text { statements from } \\
\text { Borsa Istanbul. } \\
2006-2011 .\end{array}$ & $\begin{array}{l}\text { To be listed in Corporate } \\
\text { Governance Index } \\
\text { relates negatively with } \\
\text { audit report lag. }\end{array}$ \\
\hline Vuran \& & Total equity/total & 178 non-financial & Timeliness of financial \\
\hline
\end{tabular}




\begin{tabular}{|c|c|c|c|}
\hline $\begin{array}{l}\text { Abdiloglu } \\
(2013)\end{array}$ & $\begin{array}{l}\text { assets, net } \\
\text { income, ROA, } \\
\text { ROE and current } \\
\text { ratio. }\end{array}$ & $\begin{array}{l}\text { companies from } \\
\text { Borsa Istanbul for } \\
\text { the year } 2009 \text {. }\end{array}$ & $\begin{array}{l}\text { statements is related } \\
\text { with net income, ROA } \\
\text { and current ratio. }\end{array}$ \\
\hline $\begin{array}{l}\text { Erer \& Comert } \\
(2014)\end{array}$ & $\begin{array}{l}\text { Size, profitability } \\
\text { and leverage of } \\
\text { the companies. }\end{array}$ & $\begin{array}{l}\text { Non-financial } \\
\text { companies from } \\
\text { Borsa Istanbul. } \\
\text { 2003-2010. }\end{array}$ & $\begin{array}{l}\text { No significant } \\
\text { association is found } \\
\text { between the company } \\
\text { size, profitability and } \\
\text { reporting lag. Leverage } \\
\text { is positively associated } \\
\text { with reporting lag. }\end{array}$ \\
\hline $\begin{array}{l}\text { Tuan } \\
(2016)\end{array}$ & $\begin{array}{l}\text { Professional } \\
\text { experience, } \\
\text { financial } \\
\text { expertise and } \\
\text { size of audit } \\
\text { committees. }\end{array}$ & $\begin{array}{l}\text { Corporate } \\
\text { Governance Index } \\
\text { of the Borsa } \\
\text { Istanbul. 2007- } \\
2014 \text {. }\end{array}$ & $\begin{array}{l}\text { The professional } \\
\text { experience and financial } \\
\text { expertise of audit } \\
\text { committee members } \\
\text { reduces the lag in } \\
\text { financial reporting } \\
\text { process. The lag } \\
\text { increases with the } \\
\text { number of the members } \\
\text { on audit committees. }\end{array}$ \\
\hline $\begin{array}{l}\text { Ocak \& Ozden } \\
(2018)\end{array}$ & $\begin{array}{l}\text { Gender, } \\
\text { experience, } \\
\text { education and } \\
\text { professional } \\
\text { certification of } \\
\text { signing auditors. }\end{array}$ & $\begin{array}{l}968 \text { firm-year } \\
\text { observations over } \\
\text { the period 2008- } \\
2013 \text {. }\end{array}$ & $\begin{array}{l}\text { The gender and } \\
\text { education level of } \\
\text { signing auditor have a } \\
\text { positive effect on audit } \\
\text { report lag. No statistical } \\
\text { evidence is found } \\
\text { between the experience, } \\
\text { professional certification } \\
\text { of signing auditor and } \\
\text { audit report lag. }\end{array}$ \\
\hline
\end{tabular}

According to the Table above; although characteristics of entities, audit firm, auditors and corporate governance practices that may affect timeliness of financial reporting have been examined, there is no study (to our best knowledge) investigating whether the change of the audit firm has an effect on the disclosure dates of financial reports. Thus, the hypothesis of the study, which aims to fill this gap in the literature, is developed as follows:

H0: Audit firm rotation has no effect on the disclosure date of financial reports.

In the next part of the study, the hypothesis of the research is tested and the findings are reported. 


\section{Research Methodology}

The research foces on all non-financial companies listed on the Borsa Istanbul (BIST) to provide data homogeneity and companies with unavailable data are excluded. The sample of the study consists of 1,200 company-year observations from companies' annual reports published between 2010 and 2017. The annual reports are downloaded from the companies' official websites. The aim of the research is to examine the relationship between audit firm rotation and audit report dealy. In this study, the audit report delay (ARD) is determined as a dependent variable. In audit literature, ARD is defined as the period between financial year-end of a company and the date of the signed audit report. The natural logarithm of audit report delay is used for regression analysis. Additionally, our test (independent) variable in this research is audit firm rotation which comprises any types of rotation such as voluntary and mandatory. In accordance with previous studies (Tanyi et al., 2010; Enofe et al., 2013) we use the following regression model to test our hypothesis:

$$
A R D i t=\beta 0+\beta 1 \text { AROTit }+\beta 2 \text { SIZEit }+\beta 3 \text { LEVit }+\beta 4 \text { ROAit }+\varepsilon i t
$$

There are three control variables in the model. The financial reports of large companies attract more users than the financial reports of small companies. Therefore, larger companies can be pressured to publish their financial reports early. To control the effects of company size, the SIZE variable representing the company's total assets is first added to the model and measured using the natural diary of total assets (Lee et al., 2009). A high leverage ratio indicates a high level of risk in corporate finance. This may lead to more procedures and extra time in the audit process and thus delay in financial reports. Therefore, the leverage ratio calculated by dividing total debt by total assets is added as the second control variable (Mutiara et al., 2018). It is expected that high performing companies will not be late to announce their financial reports. Therefore, the final control variable of the model is added asset return (ROA), which is an indicator of how profitable a company is relative to its total assets for the control of company performance (Lee et al., 2009).

Table 2 presents the dependent, independent and control variables and their explanations.

Table 2. Description of Variables

\begin{tabular}{ll}
\hline Variables: & Definition: \\
\hline $\begin{array}{l}\text { Dependent Variable: } \\
\text { Audit Report Delay (ARD) }\end{array}$ & $\begin{array}{l}\text { is taken as the dependent variable and is referring to } \\
\text { the number of days from the fiscal year end till the } \\
\text { date of audit report. }\end{array}$ \\
\hline $\begin{array}{l}\text { Independent Variable: } \\
\text { Audit Firm Rotation (AROT) }\end{array}$ & $\begin{array}{l}\text { Its value is set to "1" if the audit firm has rotated, and } \\
\text { "0" otherwise. }\end{array}$ \\
\hline $\begin{array}{l}\text { Control Variable: } \\
\text { Company Size (SIZE) }\end{array}$ & Natural logarithm of company's total assets. \\
\hline $\begin{array}{l}\text { Control Variable: } \\
\text { Company Leverage (LEV) }\end{array}$ & Short-term and long-term debt divided by total assets. \\
\hline $\begin{array}{l}\text { Control Variable: } \\
\text { Probability of Company } \\
\text { (ROA) }\end{array}$ & $\begin{array}{l}\text { Refers to the profitability of the company and it is } \\
\text { calculated by dividing net income (loss) by total } \\
\text { asstes. }\end{array}$ \\
\hline
\end{tabular}




\section{Ç.Ü. Sosyal Bilimler Enstitüsü Dergisi, Cilt 29, Sayı 1, 2020, Sayfa 29-41}

Table III presents summary statistics for the variables used in this study. The mean value of ARD is 65.13 days, which indicates that the average audit report delay is about 65 days, a little more than two months to complete an audit. The standard deviation value of timeliness of financial reporting is 14 days, minimum is 14 days and maximum is 129 days. Also from Table III, the mean and standard deviation of audit firm rotation are 0.10 and 0.30 , respectively. This demonstrates that about 10 percent of the sample firms are changed their auditors.

Table 3. Descriptive Statistics for the Study Variables

\begin{tabular}{lllll}
\hline & Mean & SD & Maximum & Minimum \\
\hline ARD & 65.13 & 14.55 & 14 & 129 \\
AROT & 0.10 & 0.30 & 0 & 1 \\
SIZE & 19.60 & 1.57 & 15.34 & 24.36 \\
LEV & 0.48 & 0.23 & 0.01 & 1.71 \\
ROA & 0.03 & 0.09 & -0.55 & 0.44 \\
\hline
\end{tabular}

=number of calendar days from fiscal year-end to the date of the auditor's report, =audit firm switching, =the natural $\log$ of total assets, =total liabilities divided by total assets, =net earnings divided by total asset.

To meet the requirements of the regression analysis assumptions, the correlation between the independent variables were examined. The Pearson correlation matrix in Table IV shows that the variables, in general, are not highly correlated with each other.

Table 4. Correlation Matrix between Independent Variables

\begin{tabular}{lllll}
\hline Independent Variables: & AROT & SIZE & LEV & ROA \\
\hline AROT & 1.0000 & & & \\
SIZE & 0.1602 & 1.0000 & & \\
LEV & 0.0118 & 0.0698 & 1.0000 & \\
ROA & 0.0394 & 0.2708 & -0.5140 & 1.0000 \\
\hline
\end{tabular}

=number of calendar days from fiscal year-end to the date of the auditor's report, =audit firm switching, =the natural $\log$ of total assets, =total liabilities divided by total assets, =net earnings divided by total asset.

The Ordinary Least Square (OLS) and Fixed-Effect techniques were employed in the analysis of the relationship between the dependent and independent variables after tested the classical assumption consisting of multicollinearity, normality and autocorrelation.

\section{Research Findings}

In this section, we discuss the results of regression of ARD with an eight-year period from 2010-2017. Table V, presents the regression results based on OLS and Fixed Effects Model, where the audit report delay is determined as the dependent variable and the audit firm rotation is the independent variable. According to the results of the analysis, the OLS technique shows that the coefficient of rotation for the audit firm is 3.227 positive and the $\mathrm{p}$ value is 0.004 . These results indicate that there is a statistically significant positive correlation between audit report delay and audit firm rotation at $5 \%$ 
significance level. In other words, the disclosure date of the company's financial reports is extended after the change of the audit firm.

In addition, based on the regression coefficients and their p-values in Table V, it was found that there was a statistically significant negative relationship between SIZE, LEV and ROA variables and disclosure dates of the financial reports. Moreover, the SIZE and ROA variables were statistically significant at $5 \%$ significance level, whereas the LEV variable was significant at $10 \%$ significance level.

Table 5. Regression Results

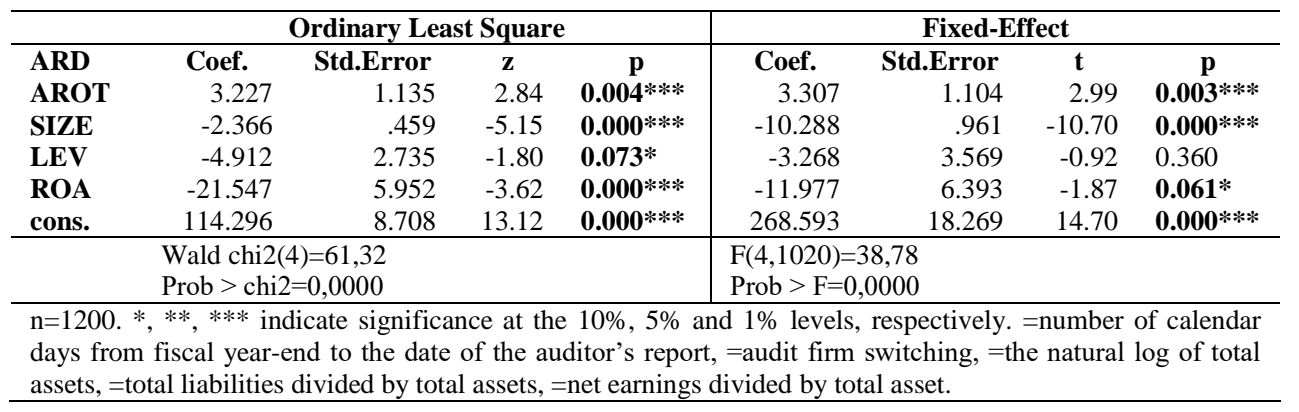

Although the OLS results show the relationship between audit report delay and auditor switching, the selection of the right technique in the analysis of the data is very important in order to obtain more reliable research results. In the literature, OLS technique is criticized for potential problems caused by neglected variables and resulting from deviations in estimation (Arioglu \& Tuan, 2014). Thus, the study data were tested with the fixed effects model in addition to the OLS method to test whether such relationships and concerns are valid even in the case of using different econometric methods of the relationships obtained with the linear regression model. According to the findings obtained from fixed effects model, the variable AROT has positive and significant effect on the dependent variable ARD. This is indicated by the coefficient (3.307) and P-value (0.003) of variable AROT. The result shows that there is a significant relationship between audit report delay and audit firm rotation of companies listed on the BIST - therefore H0 hypotheses can be rejected.

The result of the study supports the idea that an auditor may lose the specific knowledge regarding client accounting systems, records, internal control system and prior audit procedures after audit firm rotation. As a result of this situation new auditor requires more time to become familiar with client's operations and records, to have understanding of internal control system and new auditor may implement inefficient audit procedures and cause extra delays in the independent audit report by spending extra time (Myers et al., 2003; Habib \& Bhuiyan, 2011).

\section{Conclusion}

As a result of the accounting scandals, severe regulations and practices have been implemented in many countries around the world. The focus of the regulations is on efforts to enhance the quality of independent audit services. In this study, the effect of 
audit firm rotation which results in the loss of the specific audit knowledge gained by the audit tenure while is the increase in auditor-client independence on the disclosure date of the company's financial reports is discussed. Under these two different views in Turkey sample, the effect of audit firm switching on disclosure date of financial statements is investigated by using 1,200 company-year data obtained from nonfinancial companies traded in Borsa Istanbul for the period 2010 to 2017. The research findings obtained with the OLS and fixed effect models provide evidence that audit firm rotation is likely to have a negative impact on disclosure date of financial statements issued at the end of the audit process. Public Oversight Authority (POA) has the authority to regulate on audit rotation practices and shorten the periods specified in the law. While taking into consideration the advantages of audit rotation to improve auditor independence, POA should also take into account that auditor may lose specific audit knowledge about client and sector client operated in. Because timeliness of financial statements is considered one of the qualitative features of a quality financial reporting. In addition, when the country practices in this field are examined, it is seen that there is no common opinion about whether the mandatory auditor rotation practice is at the audit firm level or audit partner level. In this context, examining different country practices and taking into account and evaluating the results obtained from studies will provide benefits to the regulatory authorities.

Mandatory audit firm rotation rules, have been adopted in many countries such as Turkey, may increase auditor's independence; on the other hand, it may lead to inefficient audit procedures resulting from the lack of specific information regarding the client accounting records and operations and delays in the publication of financial reports. Within this framework, coordination and cooperation between the independent auditor and the internal audit unit and the audit committee of the company should be established in order not to lose the specific and the deeper information about the sector in which the company operates. In addition, by strengthening the communication between independent audit firms, it could create a platform where independent audit firms are able to share their experiences in different sectors. In this way, the functionality and transparency of capital markets would be increased and possible delays in financial reporting can be prevented. It is expected that the study contributes to the literature of audit rotation practices and will be beneficial for the institutions responsible for the relevant regulations.

\section{References}

Abernathy, J. L., Barnes, M., Stefaniak, C., \& Weisbarth, A. (2017). An International Perspective on Audit Report Lag: A Synthesis of the Literature and Opportunities for Future Research. International Journal of Auditing, 21 (1), 100-127. https://doi.org/10.1111/ijau.12083.

Afify, H. A. E. (2009). Determinants of audit report lag, Journal of Applied Accounting Research, 10 (1), 56-86. https://doi.org/10.1108/09675420910963397.

Aktas, R. \& Kargin, M. (2011). Timeliness of Reporting and the Quality of Financial Information, International Research Journal of Finance and Economics, 63, 71-77. 


\section{Ç.Ü. Sosyal Bilimler Enstitüsü Dergisi, Cilt 29, Sayı 1, 2020, Sayfa 29-41}

Al-Ajmi, J. (2008). Audit and reporting delays: Evidence from an emerging market. Advances in Accountin- Incorporating Advances in International Accounting, $24,217-226$.

Arioglu, E. \& Tuan, K. (2014). Speed of Adjustment: Evidence from Borsa Istanbul, Borsa Istanbul Review, 14 (2), 126-131.

Arrunada, B. \& Paz-Ares, C. (1997). Mandatory rotation of company auditors: A critical examination, International Review of Law and Economics, 17 (1), 3161.

Ashton, R. H. \& Wright, A. (1989). Identifying audit adjustments with attentiondirecting procedures, The Accounting Review, 64 (4), 710-729.

Bamber, M., Bamber, L. \& Schoderbek, M. (1993), Audit Structure and Other Determinants of Audit Report Lag: An Empirical Analysis, Auditing: A Journal of Practice and Theory, 12 (1), 1-23.

Bedard, J. \& Gendron, Y. (2010). Strengthening the financial reporting system: Can audit committees deliver?, International Journal of Auditing, 14 (2), 174-88.

Blankley, A. I., Hurtt, D. N. \& MacGregor, J. E. (2014), The relationship between audit report lags and future restatements, Auditing: A Journal of Practice \& Theory, $33(2), 27-57$.

Chambers, A. \& Penman, S. (1984). Timeliness of Reporting and The Stock-Price Reaction to Earnings Announcements, Journal of Accounting Research, 22 (1), 21-47.

Chen, CY, Lin, YC \& Lin, YC. (2008). Audit Partner Tenure, Audit Firm Tenure, and Discretionary Accruals: Does Long Auditor Tenure Impair Earnings Quality?, Contemporary Accounting Research, 25 (2), 415-445.

Dao, M. \& Pham, T. (2014). Audit tenure, auditor specialization and audit report lag, Managerial Auditing Journal, 29 (6), 490-512, https://doi.org/10.1108/MAJ07-2013-0906.

Davis L. R., Soo B.S. \& Trompeter G. M. (2009). Auditor tenure and the ability to meet or beat earnings forecasts. Contemporary Accounting Research 26, 517-548.

Dogan, M., Coskun, E. \& Celik, O. (2007), Is Timing of Financial Reporting Related to Firm Performance? An Examination on ISE Listed Companies, International Research Journal of Finance and Economics, 12, 221-223.

Dumlu, T. \& Saltoglu, M. (2011). The Timeliness of Annual Reports in Turkey: An Empirical Study, World of Accounting Science, 13(1), 1-21.

Enofe, A. O., Mgbame, C. O. \& Abadua, H. S. (2013). Audit Firm Rotation and Audit Report Lag in Nigeria, Journal of Business and Management, 12 (4), 13-19.

Erer, M. \& Comert, Ç. (2014). Timeliness of Financial Reporting in Turkey, Iktisat Issletme ve Finans Dergisi, 29 (337), 73-94.

Ettredge, M. L., Li, C. \& Sun, L. (2006). The impact of SOX Section 404 internal control quality assessment on audit delay in the SOX era, Auditing: A Journal of Practice \& Theory, 25 (2), 1-23.

Firth, M., Oliver, M.R. \& Xi, W. (2012). How Do Various Forms of Auditor Rotation Affect Audit Quality? Evidence from China, The International Journal of Accounting, 47 (1), 109-138.

Geiger, M. A. \& Raghunandan, K (2002). Auditor Tenure and Audit Reporting Failures, Auditing: A Journal of Practice \& Theory, 21 (1), 67-78. 


\section{Ç.Ü. Sosyal Bilimler Enstitüsü Dergisi, Cilt 29, Sayı 1, 2020, Sayfa 29-41}

Givoly, D. \& Palmon, D. (1982). Timeliness of annual earnings announcements: Some empirical evidence, The Accounting Review, 57 (3), 485-508.

Habib, A. \& Bhuiyan, M. B. U. (2011). Audit Firm Industry Specialization and the Audit Report Lag, Journal of International Accounting, Auditing and Taxation, 20 (1), 32-44.

IASB- The International Accounting Standards Board. (2010). "Conceptual Framework for Financial Reporting”. September 2010.

Ocak, M., \& Ozden, E. A. (2018). Signing Auditor-Specific Characteristics and Audit Report Lag: A Research from Turkey, Journal of Applied Business Research(JABR), 34 (2), 277-294. https://doi.org/10.19030/jabr.v34i2.10129

Official Gazette (2017). II-14.1 Communique on Financial Reporting in Capital Markets 29968-03.02.2017.

Ozkan, S., Karaibrahimoğlu, Y., Acar, E. \& Oz, İ. (2013). Finansal Tabloların Sunum Tarihini Etkileyen Faktörler: İMKB Firmaları Üzerine Bir Uygulama, Muhasebe Öğretim Üyeleri Bilim ve Dayanışma Vakfı (MÖDAV), 15 (3), 167 185.

Jackson, A. B., Moldrich, M. \& Roebuck, P. (2008). Mandatory Audit Firm Rotation and Audit Quality, Managerial Auditing Journal, 23 (5), 420-437.

Knechel, W. R. \& Sharma, D. S. (2012). Auditor-provided nonaudit services and audit effectiveness and efficiency: Evidence from pre- and post-SOX audit report lags, Auditing: A Journal of Practice \& Theory, 31 (4), 85-114.

Lee, H. Y., Mande, V. \& Son, M. (2009). Do Lengthy Auditor Tenure and the Provision of Non-Audit Services by the External Auditor Reduce Audit Report Lags?, International Journal of Auditing, 13 (2), 87-104.

Mohammadi, S., Mohammad M. M. \& Noori S. K. (2015). Audit Firm Rotation and Audit Report: Evidence from the Tehran Stock Exchange, South African Journal of Accounting Research, 29 (1), 1-12.

Munsif, V., Raghunandan, K. \& Dasaratha, V. R. (2012). Internal control reporting and audit report lags: Further evidence, Auditing: A Journal of Practice \& Theory, 31 (3), 203-18.

Mutiara, Y. T., Zakaria, A. \& Anggraini, R. (2018). The Influence of Company Size, Company Profit, Solvency and CPA Firm Size on Audit Report Lag, Journal of Economics, Finance and Accounting (JEFA), 5 (1), 1-10.

Myers, J. N., Myers, L. A. \& Omer, T. C. (2003). Exploring the Term of the AuditorClient Relationship and the Quality of Earnings, The Accounting Review, 78, 779-799.

Puasa, S., Salleh, M. \& Ahmad, A. (2014). Audit Committee and Timeliness of Financial Reporting: Malaysian Public Listed Companies, Middle-East Journal of Scientific Research, 22 (2), 162-175.

Schwartz, K. B. \& Soo, B. S. (1996). The association between auditor changes and reporting lags, Contemporary Accounting Research, 13 (1), 353-370.

Sultana, N., Singh, H. \& Van der Zahn, M. (2015). Audit Committee Characteristics and Audit Report Lag, International Journal of Auditing, 19, 72-87.

Tanyi, P., Raghunandan, K. \& Barua, A. (2010). Audit Report Lags after Voluntary and Involuntary Auditor Changes, Accounting Horizons, 24 (4), 671-88. 
Ç.Ü. Sosyal Bilimler Enstitüsü Dergisi, Cilt 29, Sayı 1, 2020, Sayfa 29-41

Tuan, K. (2016), Finansal Raporlama Zamanlılı̆̆ına Farklı Bir Bakış, Muhasebe ve Finansman Dergisi (MUFAD), 69, 99-114.

Turel, A. (2010), Timeliness of Financial Reporting in Emerging Capital Markets: Evidence from Turkey, Istanbul Üniversitesi İsletme Fakültesi Dergisi, 39 (2), 227-240.

Vuran, B. \& Abdioglu, B. (2013), Is Timeliness of Corporate Financial Reporting Related to Accounting Variables? Evidence from Istanbul Stock Exchange, International Journal of Business and Social Science, 4 (6), 58-70.

Yucel, E., Ertan, Y. \& Sarac, M. (2013), Kurumsal Yönetim Endeksinde Yer Alma ve Denetim Süresi İlişkisi: Konsolide Finansal Tablo Düzenleme Yükümlülüğü Olmayan Borsa İstanbul İşletmeleri Uygulaması, İstanbul Üniversitesi İşletme Fakültesi Dergisi, 42 (2), 351-363. 